\title{
РОЛЬ ВИКЛАДАЧА В ОРГАНІЗАЦІЇ НАВЧАЛЬНОГО ПРОЦЕСУ ЗА КРЕДИТНО-МОДУЛЬНОЮ СИСТЕМОЮ
}

О. І.Зарудна

ДВНЗ “Тернопільський держсавний медичний університет імені І. Я. Горбачевського МОЗ Украӥни”

\section{THE ROLE OF THE TEACHER IN ORGANIZATION OF EDUCATIONAL PROCESS ACCORDING TO THE CREDIT-MODULAR SYSTEM}

\author{
O. I. Zarudna \\ SHEI “Ternopil State Medical University by I.Ya. Horbachevsky of MPH of Ukraine”
}

\begin{abstract}
У статті проаналізовано роль викладача в організації ефективної роботи студентів, які знаходяться протягом навчального дня на одній клінічній базі.
\end{abstract}

The articles deals with a role of the teacher in organization of effective students' work, who study during the academic day at one clinical cite.

Вступ. У сучасній системі медичної освіти присутні численні фактори: стрімке зростання обсягів медичної інформації, швидка зміна та розширення наукових уявлень про патогенез багатьох патологій, недостатність часу на освоєння великого масиву необхідної інформації, нескінченні особливості фізіологічних та патологічних станів людського організму. Окрім цього, складні сучасні умови життя знижують у викладачів прагнення навчати, а в студентів - бажання навчатись, престиж освіти падає, відбувається переоцінка цінностей. Спостерігається явище намагання відповідати уявленням батьків чи старших наставників у виборі професії та подальше розчарування у навчанні у зв'язку із цим. Тому для оптимізації навчального процесу запроваджено у відповідності до Концепції розвитку університету за результатами вивчення передового міжнародного досвіду різноманітні новітні засоби, а саме: методику “єдиного дня" навчання; Z-систему освіти; матрикули практичних навичок; семестровий тестовий контроль; програму дистанційного контролю знань студентів "Moodle"; об'єктивно-структурований клінічний іспит та комунікативні навички [1].

Методика “єдиного дня" передбачає перебування на кафедрі впродовж 6-7 годин поспіль. Студенти мають можливість виконати значний обсяг практичної роботи, грунтовніше опанувати практичні навички, приділити більше часу самостійній курації хворих. При такій системі організації навчального процесу у викладача $є$ реальна можливість детально провести обговорення зі студентами найважливіших питань теми, що проходить у формі вільної дискусії, в яку активно включаються всі присутні на занятті студенти, забезпечити тематичних хворих [1].

За таких обставин існують й високі вимоги до викладача, а саме - слід відзначити обов'язкову здатність до тривалого утримання у свідомості та оперування великою кількістю, системою відомостей, інформаційних матеріалів, правил, застережень тощо. Підвищені вимоги професійна діяльність керівника групи ставить до його самоконтролю, вміння оперативно направляти своє мислення, керувати поведінкою, спілкуванням, модифікувати відносини [2, $3,4]$.

Основна частина. На кафедрі клінічної імунології, алергології та загального догляду за хворими з предмета "Клінічна імунологія та алергологія" заняття проводяться за методикою “єдиного дня” навчання. Студенти 5-го курсу знаходяться у навчальних кімнатах кафедри та відділеннях лікарні протягом 6-7 годин. Найбільша частина заняття присвячена роботі студентів біля ліжка хворого. Для цього викладач готує список тематичних пацієнтів. Студенти мають змогу навчатись на великій клінічній базі КЗ ТОР “Тернопільська університетська лікарня”, оглядати хворих у різних відділеннях лікарні, спостерігати за клінічно роботою ординаторів відділень, асистентів, доцентів та професорів, а також допомагати та брати активну участь у процесі обстеження, виявлення симптомів та оцінки додаткових методів досліджень.

(C) O. I. Зарудна 
Роль викладача у даному процесі полягає у правильній організації роботи студентів, у виборі цікавих хворих та проведенні короткої мотиваційної бесіди щодо актуальності теми заняття.

Наступна, та не менш важлива, частина заняття це семінарське заняття, яке за давньою традицією кафедри відбувається у формі співбесіди, дискусії та $\epsilon$ послідовним продовженням практичної роботи студентів у відділеннях лікарні. Отримані на практиці навички та знання після обговорення набувають важливості стають більш зрозумілими та теоретично підкріпленими. Для унаочнення ця частина заняття забезпечується таблицями, інформацією з професійних медичних видань, міжнародними рекомендаціями щодо тих чи інших нозологічних форм.

Завершується робота на кафедрі написанням тестового контролю для тих студентів, хто не скористався системою MOODLE напередодні.

Зважаючи на тривалий час перебування студентів на кафедрі протягом дня, не завжди легкий та об'ємний матеріал для засвоєння, викладач повинен вміло утримувати увагу учнів та скеровувати, направляти їхню роботу для кращого засвоєння теми. Великого значення у цьому надається спілкуванню та особливостям роботи в колективі. По-перше: робота в групі передбачає впорядкованість, узгодженість, стабільність, послідовність, чому відповідає структура заняття. По-друге: стосунки в системі “викла-

\footnotetext{
Лiтература

1. Ковальчук Л. Я. Результати реалізації новітніх методик організації навчального процесу в Тернопільському державному медичному університеті імені І. Я. Горбачевського та плани на майбутнє / Л. Я. Ковальчук // Медична освіта. -2012. - № 2. - С. 11-17.

2. Мусатов С. О. Психологія педагогічної комунікації : теоретико-методологічний аналіз / С. О. Мусатов. - Рівне :
}

дач-студент” чи “викладач-група” можуть бути успішними тільки в тому випадку, коли налагоджене спілкування та встановлено зворотний зв'язок. Тому в структурі професійних умінь керівника групи має бути вміння давати й отримувати такий зв'язок, вибудовуючи та плануючи роботу. Повідомляючи студентам свою думку, оцінюючи їхні дії та підкріплюючи все це відповідними рухами, викладач дає їм зворотний зв'язок.

Отже, провідні особистісні якості викладача - це схильність до практичних дій (а не тільки розумових, ідеально перетворюючих дійсність) за конкретних умов, нестримна активність і працездатність, енергійність у подоланні перешкод на шляху до виробленої мети, наявність власного позитивного прикладу успіху у професії.

Висновок. Важливими умовами зацікавленості студента тематикою заняття $є$ налагодженість контакту між ним та викладачем, наявність професійної мотивації, наданої викладачем, та правильна організація роботи учня протягом дня, знову ж таки забезпечена викладачем. Отже, наявність позитивних особистісних якостей викладача, високий рівень його кваліфікації в певній галузі медицини, здатність за допомогою різних форм контакту передати свої знання студентам та щира зацікавленість своєю професією - ось головні складові успішної сучасної медичної системи освіти.

Ліста-М, 2003.- 175 c.

3. Молчанова О. Педагогічне спілкування / О. Молчанова// Психологія. - 2009. - № 29-39 (365-366). - С. 2-16.

4. Донцов А. И. Психология коллектива. Методологические проблемы исследования / А. И. Донцов. - Издательство Московского университета, 1994. -С. 207. 